\title{
Radicalism in Political Perspective and Peace Education
}

\author{
Roce Marsaulina \\ Christian Religious Education Doctoral Program, Indonesian Christian University \\ Email: rocemarsaulina1@gmail.com
}

\begin{abstract}
The international community is facing the same global situation and conditions for crimes against humanity that have occurred in decades, namely the radicalism movement and international terrorism. Indonesia, as the largest country in Southeast Asia, has experienced toughening of the radicalism movement based on religion as its basic reference. Moreover, the international terrorism movement AI Qaeda and the ISIS Group (Islamic State in Iraq and Syria) have become the mecca for the radicalism movement in Indonesia. How can Indonesia face the radicalism movement, what should Indonesia do and what is the solution so that Indonesia can be minimized from the crimes of radicalism and the global terrorism movement? This is what is discussed in this article. In Indonesia, the radicalism movement not only begins from thoughts based on religious teachings but also the political, ideological and enthusiastic elements of certain groups with different views and directions. In this article, the discussion begins with how religion responds to views about radicalism and radicalism movements, especially those that occur in Indonesia, a pluralistic country with various ethnic groups, various languages, cultural and religious traditions. Indonesia is a country with Pancasila as its state ideology. Apart from Religious Education which teaches how to live amongst fellow Indonesian citizens, to respect each other and respect differences, Indonesia also has the Bhineka Tunggal Ika (Unity in Diversity) as its national motto which reinforces the Pancasila philosophy, with life's view and freedom to embrace the religion one believes in.
\end{abstract}

Keywords: Radicalism, Political Perspective, Peace Education, Indonesia.

\section{A. INTRODUCTION}

Indonesia is a country which necessitates diversity in various things, such as ethnicity, language, cultural traditions, religions and beliefs in God Almighty. This diversity is actually the national wealth that Indonesia has as a nation and as a country. Diversity and plurality are the basic reasons that stimulate substantial thinking about Indonesia, which is diverse, which is then tied into a national consensus. Although Indonesia has various differences, an awareness as one country, one nation and one Indonesian language exist. Therefore, Indonesia is a country based on Pancasila and upholds Unity in Diversity.

On 17 August 1945 Indonesia proclaimed its independence. This means that Indonesia is a sovereign country, an independent country that has the right to determine itself. Along the way, Indonesia experienced internal turmoil from certain groups questioning the country's ideology. In the political context, different ideological views have emerged among political groups that still have different orientations.

This difference in views then gave birth to political upheaval from a certain group that attempted to undermine Indonesia. In 1948 there was a rebellion that was 
stimulated by the Indonesian Communist Party, in 1965 there was the September 30 Movement Rebellion or what was known as the G30 / S Rebellion by the Indonesian Communist Party. Not only that, other movements also took place in several regions of the Republic of Indonesia.

In this connection, history records that Indonesia faced movements that tended to base themselves on radicalism. After the G30S / PKI movement, Indonesia then gave birth to a new government known as the New Order led by President Soeharto. Even during the New Order era, Indonesia was still experiencing various socio-political upheavals. Of course, the basis of the socio-political upheaval is based on a narrow understanding of radicalism.

\section{B. RESULT AND DISCUSSION}

\section{Overview of Radicalism in Indonesia}

Radicalism is the beliefs by a certain group of people that advocate change in a revolutionary way and to achieve their goals using various means, even in the most extreme ways such as using violence, both symbolic and physical.

Religious radicalism is experiencing an increasingly massive development in Indonesia. According to Muhammad A.S Hikam in his book Deradicalization, it is explained that this movement generally originates from the Wahabism school which tends to emphasize the purity of religious life in accordance with religious law. On a global scale this understanding is based on the Movement.

In his identity, Prof. Azyumardi Azra also mentioned this element and added several other elements as a characteristic of this movement, namely rejecting Pancasila, Bhinneka Tunggal Ika and the Unitary State of the Republic of Indonesia (NKRI), practicing an attitude of takfiri which infidels fellow religious brothers with different views and reject tolerance and cooperation with followers of other religions. Overall religious radicalism is a religious movement based on the literal interpretation of religious law for the sake of straight and pure religious understanding and practice, and therefore rejects Pancasila and tolerance.

Since 2002, Indonesia has become a place that is vulnerable to acts of terrorism. Starting from the province of Bali with a bomb tragedy that claimed more than 200 lives. In the following years, Indonesia again experienced various bomb terror such as the bombing of the JW Marriot Hotel, the Australian Embassy, the Bali Bombing II and the Kampung Melayu Bombing which claimed innocent lives. The terrorist bombing took place again on Sunday, March 28, 2021, when Christians were worshiping at the Makassar Cathedral Church. The suicide bombing in front of the Makassar Cathedral Church was carried out by a husband and wife couple named Lukman and Yogi Sahfiti Fortuna. This suicide bombing left 20 people injured.

Three days after the terror bombing at the Makassar Cathedral Church, on March 31, 2021, another terrorist act occurred at the Indonesian National Police Headquarters. The shooting at the Police Headquarters was carried out by a woman named Zakiah Aini, 25 years old. The Police then paralyzed the terror act and the perpetrator died after being shot by the police. 


\section{The Reality in Indonesia as a Nation: Religion, Politics and Power}

"In particular, the term religion refers to an institution with a group of people who gather regularly for worship and receive teachings that offer a way of connecting individuals with something that is seen as the deepest, highest reality of reality." Many people think that religion makes a positive contribution to society, it can indeed happen, but the role of religion can also make negative contributions and divisions.

Contrary to some theorists, religion not only plays an integrative role and creates social harmony in society, but also a divisive role. Reading this opinion, Geertz clearly sees that religion can bring disintegration.

Religion is an institution produced by power and knowledge like the society in Indonesia. They cannot be separated from the mechanisms and techniques of normative and disciplinary power. Even at the beginning of independence, there was an indication of division related to the "Jakarta Charter", but fortunately because of the greatness of the soul and the generosity of the nation's fathers who placed national unity as far more important than just Islamic law that must be implemented.

Politics has several meanings. Some are related to government, such as matters of managing, directing and implementing general policies and decisions or policies concerning political parties that play a role in state life, fields of study related to social civil problems and developing approaches for solutions to these problems.

Activities related to relations between nations and other social groups in relations to cases of the use of state power. Politics is part of ethics that deals with humans in group activities. What the fathers of the Indonesian nation did in defining and making political concepts were beautiful and good, but in practice it was often off the mark, namely the "Guided Democracy" proclaimed by President Soekarno and the "Pancasila Democracy" proclaimed by President Soeharto.

In practice, the role of religion cannot be eliminated just like that and the dichotomy of the majority of minorities is inherent, especially religion, which is echoed as the spirit that underlies all aspects of life, so that at the beginning of the process of the birth of this republic there was also a clash in the name of religion. The "Jakarta Charter" is an example of the one on December 21, 2018 at 9:18 a.m.).

Religion has also become part of politics with the formation of the department of religion after the establishment of the Republic of Indonesia with various directorates general such as the directorate general for Hindu Buddhist guidance, the director general for Christian community guidance, and the director general for Islamic Community guidance, which shows the state's role in religious affairs.

Religion can be said to shape individual subjectivity and will influence the individual's views on politics, economics and religion itself. It needs to be realized that religion has been the pillar of economics and politics for centuries, then secularism and liberalism developed which wished to separate religion from the state. 
The Indonesian nation recognize "Bhinneka Tunggal Ika" which should be able to accept and accommodate a pluralistic society. Towards independence, a formulation was made regarding the contents of Pancasila, Soekarno initiated Pancasila by not placing religious elements in the first sequence and not using the word "The One and Only" but using "The Cultural One". However, it is important to know that Soekarno also proposed a different editorial from the one that we read about this divine principle. What Soekarno proposed was "a cultured divinity, a deity with noble character, a deity that respects one another." These facts indicate the existence of pessimism from Soekarno himself if the country to be formed was too thick with religious nuances. The pessimism then became evident at a later date. These days we see how the first precepts were used by a number of circles to limit religious freedom. The first precepts are used to discriminate against others.

\section{Pancasila VS Radicalism}

The question then is what is really going on in this country? According to Professor of Political Science at the Defense University who is also known as an observer of terrorism, Professor Salim Said, the presence of terrorism must be seen in the context of socio-politics and history, especially in Indonesia.

Salim Said said, "We have to find out what really happened. I see it more as a political problem than a religion. Why are there children of the nation who want to go to Syria and join ISIS. Surprisingly, they left with their wife and children and their families. What they are looking for, and so on. Besides that, there are still many problems in Indonesia that require a long discussion for that. "

Indonesia is a very large plural country. The acculturation was too deep, so the process of becoming Indonesia had to run as a whole. Therefore, an anti-terrorist movement must be built in Indonesia to save Indonesia in the Indonesian context. The results of research by the Alvara Research Center in September-October 2017 were written in the book titled Radicalism Rising among Educated People. In the introduction, the book states that religious radicalism that has developed globally, especially in the Middle East and even in Indonesia, is a narrow view of religion that ultimately teaches intolerance and violence based on religious fanaticism. The basic character of religious radicalism is in stark contrast to Pancasila.

As the foundation and soul that underlies the building of this nation and country, the presence of Pancasila actually protects and guarantees the diversity of primordial identities of the Indonesian people. In that sense, Pancasila guides this nation to be inclusive, moderate in presenting our ethnic and religious identity, tolerance and mutual cooperation as the distinctive personality of the Indonesian nation whose destiny is plural.

The function and role of Pancasila as a source of law include: First, as the glue for the unity of national law in the sense that every legal rule regulating aspects of life must not conflict with Pancasila as a philosophy, view of life and the basis of the state. Second, as the ideals of national law, it means that all the rules that arise and 
regulate the life of the community are formed to realize the ideals of a nation and state based on the values of the whole Pancasila.

\section{Peace Education}

Peace Education is an important thing in the life of every individual and starts from the environment of the Family, Church, and Society. In its philosophy, Peace Education teaches non-violence, love, mercy, and respect for all life, also teaches about the causes of conflict and provides knowledge and other alternative ways besides violence in efforts to deal with it.

According to Ian M. Harris and Marry Lee Morrison, "Peace Education is a wholeness created with and through oneself, other people and other life, the earth and the greater whole of which we are a part." The Peace Education process includes, among other things, empowering people with the skills, attitudes and knowledge to create a world in which conflicts are resolved peacefully without violence and build a sustainable environment.

The task of Peace Education is a task that is inseparable from the task of Christian Religious Education (Pendidikan Agama Kristen, PAK) because it is an integral part of the PAK. The church has a pedagogical duty to participate in the Peace Education Movement, not only for its citizens, but also outside its community. Peace Education in PAK enables educators to be able to carry out the reconciliation tasks themselves, namely love, justice, truth, mercy, forgiveness, care, harmonization, reconciliation, respect for all creatures and the environment for the integrity of creation by actualizing knowledge, skills, attitudes and values for bringing about behavior change with the aim of preventing conflict and violence and conflict resolution.

Churches and Educational Institutions are ministers of reconciliation. In addition to educating human beings to be dignified, noble and good moral characters, the Church and Educational Institutions are even more responsible for making educators as human beings who have peace and become agents of peace.

One of the methods for the Church to preach the Kingdom of God, the Gospel or the Good News is through formal Christian Religious Education (PAK) in schools, as well as informal PAK in families and the Church. PAK is an integral part of Church presence, because teaching about the mission and vision of the Kingdom of God is always pursued in various forms. The presence of the Church is a representation of God's presence in the world as a servant of reconciliation. Thus, PAK has the spirituality of the Kingdom of God. It is at this main point that the PAK has an important function for reconciliation. As stated in the previous section, quoting Groome, it becomes clear that peace and justice are integral parts of PAK. Groome also emphasized that PAK is part of an effort to represent God's presence in the world with the vision of the Kingdom of God. So, PAK is very important and strategic in Peace Education. Peace Education can help fight the culture of violence that is so 
rapidly dominating human life, so that the role of PAK in Peace Education is to build a culture of peace from an early age.

Quoting what Andar Ismail said, "the key to a successful human life is love of peace." Humans must have an inner sensitivity with a sense of harmony that must be possessed. Peace Education enables humans to be able to free themselves from inner struggles that are still filled with a sense of insecurity. Humans must have a soul full of love and peace, and have the knowledge and skills to make atonement. In Peace Education, humans must have the principles of justice and truth, solidarity and cooperation as well as respect and tolerance.

Ian Haris and UNICEF emphasize these principles, that all aspects of Peace Education must be achieved, namely knowledge, skills, attitudes and values. Humans cannot choose only one aspect to be done, but all these aspects cannot be separated from one another and are closely related.

\section{CONCLUSION}

Indonesia as a plural, pluralistic and diverse country in the early days of its independence in 1945, underwent a test related to basic ideas about the diversity of life as a society, nation and state. Contestation of different thoughts cannot be avoided because of the basic reasons for the interests of groups or political thoughts in Indonesia, through their political figures.

In fact, Indonesia stands as a nation and a state because it understands the accentuation of various understandings of differences. From a political perspective, this difference is a necessity that cannot be denied. One of them is religious differences that stimulate different perspectives in understanding the basic objectivity of the life of society, nation and state.

The emergence of radical thoughts or tend to stimulate radicalism movements in Indonesia because of the synergy of the power of religious thought and the power of political thought with political ideology and power. In this context, radicalism can be moved when it finds momentum and the movement includes the political power agenda of a certain group. Therefore, it is possible for radical attitudes to be exploited by other parties, especially extreme groups whose existence tries to turn the radicalism movement as a snare to create turmoil that can trigger horizontal conflicts and cast aside from its strong root objective.

From a political perspective, Pancasila has a strategic role in synergizing positive thoughts of national life in accordance with the ideals and goals of the independence of the Republic of Indonesia. In this case, Pancasila has contributed to the egoism of the radicalism movement in Indonesia. As the basis of the state and the view of life as a nation and state, Pancasila is a way of life that holds together and has a synergistic power that is endeavored to anticipate the destructive movement of radicalism in Indonesia in its various moments.

In addition, Peace Education as an important part of Christians has an urgency for a tolerant life between humans, in this case how Christians roll out the red carpet for a peaceful life among Indonesian citizens. Thus, this Peace Education reaches the 
basic elements of our understanding of the plurality of the Indonesian nation as a nation that binds itself to a national consensus: Pancasila and Bhinneka Tunggal Ika.

\section{REFERENCES}

1. Ali, H. \& Purwandi. L. (2018). Radicalism Rising Among Educated People?. Jakarta: Alvara Research Institute.

2. Geertz, C. (1981). Abangan, Priyayi Santri in Javanese Society. Jakarta: Dunia Pustaka Jawa.

3. Good, L. (2005). Dictionary of Philosophy. Jakarta: Gramedia Pustaka Utama.

4. Groome, T. H. (2010). Christian Religious Education. Jakarta: BPK Gunung Mulia.

5. Helmi, E. (2012). Philosophy of law. Bandung: Pustaka Setia.

6. Hikam, M. (n.d). Deradicalization of the Role of Civil Society to Combat Radicalism.

7. http://wartawarga.gunadarma.ac.id/2011/06/demokrasi-pancasila-demokrasiliberal/

8. Marsaulina, R. (2019). Building a Fortress of Anti-Radicalism. Arrabona Journal, 1(2).

9. Rantung, D. A. (2017). Conflict Resolution within Organizations. Jakarta: BPK Gunung Mulia.

10. Saidiman, A. Cultural Deity. Retrieved from http://islamlib.com/id/artikel/ketuhanan-yang-berkebultur 